\title{
Podejmowanie tematu naukometrii i bibliometrii w Polsce w latach 2015-2017
}

\author{
Magdalena Sznigir
}

\begin{abstract}
Abstrakt
Cel/Teza: Celem badania omówionego w artykule było zidentyfikowanie problematyki podejmowanej przez polskich badaczy w piśmiennictwie, którego przedmiotem są analizy naukometryczne i bibliometryczne, opublikowanym w latach 2015-2017.

Koncepcja/Metody badań: Badanie zostało oparte na danych pobranych z bibliografii polskiej naukometrii, tworzonej przez Scholarly Communication Research Group (http://sc.amu.edu.pl/ bibliography). Do oceny zmian ilościowych piśmiennictwa w badanym czasie, określenia struktury tematycznej oraz wskazania najbardziej aktywnych autorów i czasopism, zastosowano metodę statystyczną.

Wyniki i wnioski: W bibliografii Scholary Communication Research Group w latach 2015-2017 zarejestrowano 268 prac polskich badaczy, związanych z naukometrią i bibliometrią. W piśmiennictwie tym wyróżniono cztery kategorie publikacji: badania, w których bibliometria jest wykorzystana jako metoda badawcza (44\%), prace teoretyczne (37\%), komentarze i polemiki (15.7\%) oraz inne dokumenty (3.3\%). Analiza czasopism wykazała sporadyczne podejmowanie tematu naukometrii i bibliometrii przez periodyki z różnych dziedzin (m.in. humanistycznych, technicznych, medycznych). Analiza autorów wykazała, że badacze podejmują analizowany temat sporadycznie oraz to, że jedynie nieliczni naukowcy prowadzą badania nad tym zagadnieniem długofalowo.

Oryginalność/Wartość poznawcza: Artykuł porządkuje wiedzę o aktualnym kontekście podejmowanych badań naukometrycznych i bibliometrycznych w Polsce.
\end{abstract}

\section{Słowa kluczowe}

Badania w Polsce. Bibliometria. Informacja naukowa. Naukometria.

Otrzymany: 26 kwietnia 2018. Zrecenzowany: 13 maja 2018. Poprawiony: 21 maja 2018. Zaakceptowany: 26 czerwca 2018.

\section{Wstęp}

Naukometria (ang. Scientometrics) zajmuje się ilościową analizą wszystkich elementów składających się na organizację nauki i jej dorobek. Wśród elementów tych można wymienić m.in. działalność jednostek naukowych, parametryzację nauki, politykę państwa wobec nauki w danym kraju oraz badanie piśmiennictwa. Naukometria jest dyscypliną empiryczną, znajdującą się w kręgu badań naukoznawczych. Według Ludomily Ivanchevej zadaniem naukometrii jest badanie rozwoju nauki za pomocą metod statystycznych i ilościowych (Ivancheva, 2008). W odróżnieniu od dziedzin takich jak socjologia czy filozofia, naukometria z metodologicznego punktu widzenia, traktuje wytwory nauki (prace naukowe, instytucje) jako składniki procesu informacyjnego, które są mierzalne i które można ująć jakościowo (za pomocą wybranych kategorii) albo ilościowo (za pomocą liczb). 
Bibliometria bywa traktowana jako subdyscyplina naukometrii badająca piśmiennictwo naukowe, która pozwala na odkrycie podstawowych praw w rozwoju nauki (Broadus, 1987). Już jej pierwsza definicja z 1969 r., autorstwa Alana Pritcharda, mówi, że jest to zastosowanie metod matematycznych i statystycznych do badania książeki innych form komunikacji piśmienniczej (Pritchard, 1969). Z kolei Wanda Pindlowa jako cel bibliometrii wskazuje otrzymanie obrazu statystycznego rozkładu procesów odnoszących się do rozproszenia (rozkładu), utylizacji i powiązań literatury w znaczeniu grupy odpowiednio dobranych dokumentów (Pindlowa, 1988).

Podstawą badań bibliometrycznych jest rejestracja bibliograficzna dokumentów, która pozwala na badania nad rozmiarem i charakterem wydawanej literatury. Analiza bibliograficzna jest typem badań związanych z dokumentami jako obiektami, ale nie nośnikami informacji. Tak więc, bibliometria bada elementy opisu bibliograficznego jako jednostki badania statystycznego, np. nazwisko autora, czasopismo, rok wydania publikacji. Tradycyjne badania bibliograficzne, które wykorzystują metody statystyczne, skupione są na aspektach historyczno-księgoznawczych bądź historyczno-naukoznawczych spisów bibliograficznych (Skalska-Zlat, 1996).

Obecnie naukometria i bibliometria są wykorzystywane przez przedstawicieli różnych dziedzin i dyscyplin naukowych do analizy piśmiennictwa naukowego, kierunków rozwoju nauki, aktywności autorów, czasopism i instytucji naukowych. Badania biblio- i naukometryczne są też wykorzystywane w ewaluacji nauki, m.in. w celu kształtowania polityki naukowej, optymalizacji organizacji nauki i jej finansowania. Na podstawie tego typu badań tworzone są rankingi najbardziej wpływowych czasopism naukowych, naukowców i zatrudniających ich placówek, a przypisywane poszczególnym jednostkom indeksy, wskazujące wartość określonego rodzaju miary ich aktywności naukowej, wykorzystywane są w podejmowaniu decyzji, np. o przyznawaniu grantów badawczych. W tym sensie naukometria ma obecnie istotny wpływ na rozwój nauki. W takim kontekście warto przyjrzeć się temu, jak kształtuje się rozwój samej naukometrii w Polsce.

W artykule podjęto próbę ustalenia aktualnych kierunków badań prowadzonych przez polskich badaczy w zakresie bibliometrii i naukometrii w trzech ostatnich latach, a więc w okresie 2015-2017. Jest to okres narastającej dyskusji o skuteczności metod ewaluacji nauki opartych na naukometrii oraz o potrzebie zmian w organizacji działalności naukowej w Polsce i zasad jej finansowania. Ciekawe jest zatem to, czy i w jakim stopniu dyskusje te miały wpływ na wybór zagadnień podejmowanych ostatnio przez badaczy naukometrii i bibliometrii.

W celu wyróżnienia problemów badawczych, w kontekście których poruszany był temat naukometrii i bibliometrii w Polsce w latach 2015-2017 przeprowadzono analizę zawartości bibliografii polskiej naukometrii tworzonej przez Scholarly Communication Research Group (SCRG, http://sc.amu.edu.pl/bibliography). SCRG jest jednostką badawczą, kierowaną przez Emanuela Kulczyckiego i afiliowaną w Instytucie Filozofii, na Wydziale Nauk Społecznych Uniwersytetu im. Adama Mickiewicza w Poznaniu. Bibliografia SCRG rejestruje artykuły, książki, rozdziały w pracach zbiorowych (artykuły w monografiach), recenzje oraz dokumenty elektroniczne poświęcone bibliometrii, naukometrii i ewaluacji nauki. Gromadzone są w niej opisy publikacji polskich badaczy i publikacji autorów obcych, które dotyczą polskiej nauki (SCRG, 2018).

Do oceny zmian ilościowych piśmiennictwa w wybranym okresie, określenia jego struktury tematycznej oraz wskazania najbardziej aktywnych w badanym okresie autorów i czasopism, zastosowano metodę statystyczną. 


\section{Badania nad naukometrią i bibliometrią w Polsce w latach 2015-2017}

W analizowanej bibliografii zarejestrowano 268 dokumentów opublikowanych w latach 2015-2017, które dotyczą zagadnień naukometrii i bibliometrii. Wśród tych publikacji można wyróżnić dokumenty samoistne i niesamoistne. Dominującą grupą są prace opublikowane niesamoistnie, stanowią one $95.5 \%$ analizowanej literatury. Najliczniejszą grupę publikacji stanowią artykuły w czasopismach (78\%), rozdziały w pracach zbiorowych (artykuły w monografii) stanowią $17 \%$ wszystkich publikacji. Wśród prac wydanych samoistnie (4.5\%) występują: jedna książka oraz inne dokumenty wydane samodzielnie $\mathrm{w}$ formie tradycyjnej lub online (bibliografia, dysertacja, raporty oraz prezentacje multimedialne). Jedyna książka wydana w analizowanym okresie to praca zbiorowa Komunikacja naukowa $w$ humanistyce pod redakcją E. Kulczyckiego (2017). Wobec faktu, iż w badanym okresie w bibliografii SCRG zarejestrowano tylko jedną publikację książkową, dalsza analiza piśmiennictwa wykazanego w tym zbiorze skupiona jest na publikacjach niesamoistnych wydawniczo. Tabela 1 prezentuje chronologiczny rozkład publikacji wszystkich typów $\mathrm{w}$ analizowanym zbiorze.

Tab. 1. Chronologiczny rozkład publikacji

\begin{tabular}{|c|c|c|c|c|c|}
\hline \multirow{2}{*}{\multicolumn{2}{|c|}{ Rodzaj publikacji }} & \multicolumn{3}{|c|}{$\begin{array}{c}\text { Liczba prac } \\
\text { opublikowanych w latach }\end{array}$} & \multirow{2}{*}{$\begin{array}{c}\text { Lączna liczba prac } \\
\text { opublikowanych } \\
\text { w okresie } \\
2015-2017\end{array}$} \\
\hline & & 2015 & 2016 & 2017 & \\
\hline \multirow{2}{*}{$\begin{array}{l}\text { Wydawnictwa } \\
\text { niesamoistne }\end{array}$} & $\begin{array}{l}\text { artykuł } \\
\text { w czasopiśmie }\end{array}$ & 83 & 60 & 67 & 210 \\
\hline & $\begin{array}{l}\text { rozdział w pracy } \\
\text { zbiorowej (artykuł } \\
\text { w monografii) }\end{array}$ & 25 & 10 & 11 & 46 \\
\hline \multirow{2}{*}{$\begin{array}{l}\text { Wydawnictwa } \\
\text { samoistne }\end{array}$} & książka & - & 1 & - & 1 \\
\hline & inne & 5 & 4 & 2 & 11 \\
\hline \multicolumn{2}{|l|}{ Razem } & 113 & 75 & 80 & 268 \\
\hline
\end{tabular}

\subsection{Czasopisma publikujace artykuty o tematyce bibliometrycznej i naukometrycznej}

Artykuły dotyczące zagadnień biblio- i naukometrii, zarejestrowane w bibliografii SCRG zostały opublikowane na łamach 97 czasopism. Trzeba zauważyć, że polskie piśmiennictwo bibliometryczne i naukometryczne jest silnie rozproszone. Średnio jedno czasopismo w ciągu analizowanych trzech lat opublikowało dwa artykuły poświęcone tej tematyce; 73\% czasopism (71 periodyków) opublikowało prace związane z naukometrią i bibliometrią tylko jeden raz, a $12 \%$ (11 periodyków) dwa razy. W dwóch czasopismach ukazały się po trzy artykuły. Najwięcej artykułów poświęconych analizom biblio- i naukometrycznym wydano na łamach czasopisma PAUza Akademicka (w bibliografii SCRG odnotowanej 
jako PAUza) - informacyjno-publicystycznym tygodniku Polskiej Akademii Umiejętności (łącznie 24 artykuły wciągu trzech lat). W tabeli 2 zestawiono dane dotyczące rozkładu liczby artykułów poświęconych biblio- i naukometrii dla czasopism, w których ukazały się co najmniej cztery takie artykuły.

Wyniki analizy ilościowego rozkładu artykułów w czasopismach wskazują na sporadyczne podejmowanie zagadnień naukometrii i bibliometrii oraz brak stabilności zainteresowania czasopism w publikowaniu tego typu treści. Wniosek ten nie dotyczy oczywiście takich czasopism jak Scientometrics i Journal of Informetrics, które są międzynarodowymi czasopismami naukowymi skupionymi właśnie na interesującej nas tematyce. W tym przypadku nieduża liczba artykułów z tych czasopism, zarejestrowanych w bibliografii SCRG, wynika z przyjętego zakresu i zasięgu geograficznego tej bibliografii, tj. rejestrowania w niej wyłącznie artykułów, które dotyczą polskiej nauki lub których autorami są polscy badacze.

Tab. 2. Czasopisma, które opublikowały cztery

lub więcej artykułów związanych z bibliometrią lub naukometrią

\begin{tabular}{|c|c|c|c|c|}
\hline \multirow{2}{*}{ Czasopismo } & \multicolumn{3}{|c|}{$\begin{array}{l}\text { Liczba opublikowanych } \\
\text { tekstów w roku }\end{array}$} & \multirow{2}{*}{$\begin{array}{c}\text { Lączna liczba } \\
\text { tekstów } \\
\text { opublikowanych } \\
\text { w latach 2015-17 }\end{array}$} \\
\hline & 2015 & 2016 & 2017 & \\
\hline PAUza Akademicka & 16 & 1 & 7 & 24 \\
\hline Nowotwory. Journal of Oncology & 14 & - & - & 14 \\
\hline Nauka i Szkolnictwo Wyższe & 1 & - & 11 & 12 \\
\hline Nauka & 2 & 5 & 3 & 10 \\
\hline Forum Akademickie & 3 & 4 & 1 & 8 \\
\hline Biuletyn EBIB & - & - & 8 & 8 \\
\hline Scientometrics & 4 & 1 & 2 & 7 \\
\hline Zagadnienia Informacji Naukowej & 3 & 2 & 2 & 7 \\
\hline $\begin{array}{l}\text { Elektronika.Konstrukcje, } \\
\text { Technologie, Zastosowania }\end{array}$ & 2 & 3 & - & 5 \\
\hline Zagadnienia Naukoznawstwa & 1 & 3 & - & 4 \\
\hline Przegląd Elektrotechniczny & - & 2 & 2 & 4 \\
\hline Journal of Informetrics & 2 & - & 2 & 4 \\
\hline
\end{tabular}

Wśród analizowanych czasopism można wyróżnić dwie grupy periodyków: czasopisma naukowe oraz czasopisma informacyjno-publicystyczne, dotyczące nauki. Wśród czasopism naukowych występują periodyki z dziedzin zarówno humanistycznych (np. historyczne, psychologiczne, socjologiczne i językoznawcze), jak i technicznych, medycznych i ekonomicznych. A zatem, zauważyć można, iż temat naukometrii oraz wykorzystywania metod bibliometrycznych podejmowany jest przez badaczy reprezentujących różne dziedziny naukowe, a także iż tą tematyką zainteresowane są czasopisma zajmujące się dziedzinami i dyscyplinami, których dotyczą określone badania biblio- i naukometryczne. Wśród 
czasopism publicystyczno-informacyjnych tematyka biblio- i naukometryczna najczęściej podejmowana jest w wymienionym już wcześniej periodyku PAUza Akademicka oraz w Forum Akademickie. Na łamach tych czasopism prowadzona jest aktualna debata na temat naukometrii, parametryzacji oraz sytuacji nauki w Polsce.

Czasopismem najaktywniej publikującym na temat naukometrii i bibliometrii w latach 2015-2017 jest PAUza Akademicka - łącznie 24 teksty w ciągu trzech ostatnich lat. Drugim periodykiem z największą liczbą artykułów na temat bibliometrii i naukometrii jest medyczne czasopismo Nowotwory. Journal of Oncology. Trzeba jednak zauważyć, że wszystkie teksty na ten temat opublikowane w tym czasopiśmie pochodzą z 2015 r., kiedy to w numerze 6 ukazał się artykuł redakcyjny Edwarda Towpika IF-mania: Journal Impact Factor nie jest właściwym wskaźnikiem oceniania wyników badań naukowych, indywidualnych uczonych ani ośrodków badawczych, po którym zamieszczono 13 artykułów polemicznych, stanowiących wypowiedzi opublikowane w ramach dyskusji zainicjowanej tym artykułem. Trzecim czasopismem pod względem największej liczby artykułów o problematyce biblioi naukometrycznej jest Nauka i Szkolnictwo Wyższe. Podobnie jak w przypadku czasopisma Nowotwory. Journal of Oncology, również w Nauce i Szkolnictwie Wyższym niemal wszystkie artykuły zostały opublikowane w jednym numerze. Numer 1 z 2017 r. tego periodyku zamieścił 10 tekstów (osiem artykułów, recenzję i artykuł wstępny), które nawiązują do naukometrii lub dotyczą badań, w których wykorzystano metodę bibliometryczną.

Wśród zarejestrowanych czasopism tylko pięć charakteryzuje ciągłość w publikowaniu treści związanych z analizowanym zagadnieniem. Oprócz PAUzy Akademickiej i Forum Akademickiego, są to czasopisma Nauka, Scientometrics i Zagadnienia Informacji Naukowej-Studia Informacyjne. Świadczy to o długofalowym i konsekwentnym zainteresowaniu badaniami naukometrycznymi i bibliometrycznymi przez, przede wszystkim, czasopisma związane generalnie z problematyką nauki i działalności naukowej (w tym czasopisma informacyjno-publicystyczne) oraz z naukometrią i informacją naukową.

\subsection{Autorzy}

W analizowanym zbiorze literatury zarejestrowano 176 autorów. Większość, bo 74\% (131) autorów opublikowało po jednej pracy, $16.5 \%$ (29) opublikowało po dwie, a 4\% (7) po trzy. W tabeli 3 zestawiono nazwiska autorów, którzy opublikowali w latach 2015-2017 cztery lub więcej tekstów poświęconych omawianej tu tematyce. W badanym zbiorze średnio na jednego autora przypada 1.5 publikacji. Duża liczba autorów z jedną publikacją i generalnie niski wskaźnik publikacji przypadających na jednego autora świadczą o sporadycznym podejmowaniu tematu naukometrii i bibliometrii przez polskich badaczy. Dodatkowo należy zauważyć, że tylko czterech autorów (Emanuel Kulczycki, Jerzy Marian Brzeziński, Aneta Drabek i Andrzej Kajetan Wróblewski) opublikowało swoje prace w każdym roku $\mathrm{z}$ analizowanego okresu. Obserwacje te wskazują, że bardzo wąska jest grupa polskich naukowców, którzy prowadzą długofalowe badania biblio- i naukometryczne.

Analiza wybranego do badań wykazu publikacji wskazuje, że najaktywniejszym autorem w badanym czasie był Emanuel Kulczycki, który opublikował 14 prac. Są wśród nich zarówno badania empiryczne, jak i rozprawy teoretyczne oraz polemiki i komentarze. Drugim wśród najaktywniejszych autorów był Michał Kokowski, który w latach 2015-2017 opublikował dziewięć prac związanych z naukometrią i bibliometrią. Wśród jego publikacji 
znajdują się prace teoretyczne, analizy, komentarze oraz bibliografia prac naukometryczno-bibliometryczno-informetrycznych.

Tab. 3. Autorzy, którzy opublikowali cztery lub więcej prac

\begin{tabular}{|c|c|c|c|c|}
\hline \multirow{2}{*}{ Autor } & \multicolumn{3}{|c|}{ Liczba publikacji w roku } & \multirow{2}{*}{$\begin{array}{l}\text { Lączna liczba publikacji } \\
\text { w latach } 2015-17\end{array}$} \\
\hline & 2015 & 2016 & 2017 & \\
\hline Emanuel Kulczycki & 2 & 3 & 9 & 14 \\
\hline Michał Kokowski & 6 & 3 & - & 9 \\
\hline Jerzy Marian Brzeziński & 4 & 1 & 1 & 6 \\
\hline Ryszard. S. Romaniuk & 2 & 3 & - & 5 \\
\hline Anna Małgorzata Kamińska & - & - & 5 & 5 \\
\hline Witold Sygocki & - & 3 & 2 & 5 \\
\hline Aneta Drabek & 2 & 1 & 2 & 5 \\
\hline Andrzej Kajetan Wróblewski & 3 & 1 & 1 & 5 \\
\hline Magdalena Olczyk & 1 & 3 & - & 4 \\
\hline
\end{tabular}

\subsection{Charakter i tematyka rozważań nad bibliometria i naukometria}

Wśród zarejestrowanych w bibliografii SCRG publikacji dotyczących naukometrii i bibliometrii z lat 2015-2017, można wyróżnić cztery grupy dokumentów według sposobu, w jaki podejmowane są w nich te zagadnienia:

- prace badawcze, w których bibliometria lub naukometria są wykorzystywane jako metoda badawcza - grupa ta obejmuje $44 \%$ badanych publikacji;

- prace o charakterze teoretycznym - opisujące metody badawcze, ich wykorzystywanie oraz historię - grupa ta obejmuje $37 \%$ badanej literatury;

- $\quad$ komentarze i polemiki - w grupie tej znajdują się artykuły będące polemikami oraz komentarzami do badań; obejmuje ona $15.7 \%$ publikacji zawartych w analizowanym zbiorze;

- $\quad$ inne - do grupy tej (3.3\% analizowanego zbioru) zakwalifikowano m.in. recenzje, bibliografie i listy, które nawiązują do tematów naukometrii i bibliometrii, jednak nie mieszczą się w żadnej z powyższych kategorii.

Tabela 4 przedstawia ilościowe zestawienie w poszczególnych latach publikacji według sposobu ujmowania w nich tematyki biblio- i naukometrycznej.

Wśród prac, w których bibliometria i naukometria zostały wykorzystane jako metoda badań można wyróżnić sześć typów analiz:

- analiza piśmiennictwa konkretnego zagadnienia - jest to najliczniejsza podkategoria badań empirycznych. Badacze podejmują analizy piśmiennictwa wybranych zagadnień wykorzystując bibliometrię jako metodę badawczą. Analizowane zjawiska dotyczą szerokiego spektrum tematów w ramach różnych dyscyplin, m.in. roli systemu patentowego w dyfuzji wiedzy (Niklewicz-Pijaczyńska, 2015), konkurencyjności (Olczyk, 2016), podejmowania tematu upowszechniania czytelnictwa (Kamińska, 
2015), edukacji przedsiębiorczości (Wach, 2016), aktualnych tematów publikacji w poszczególnych bazach danych (Bartol \& Mackiewicz-Talarczyk, 2015);

- analiza czasopism - badania te obejmują analizy cytowań czasopism i ich obecności w bazach danych, wykazach i rankingach. Prace te dotyczą wybranego czasopisma, np. Kultura - Społeczeństwo - Edukacja (Jaskulska, 2015) lub periodyków w ramach wybranej dziedziny, np. bibliotekoznawstwa i informatologii (Roszkowski \& Włodarczyk, 2016) lub pedagogiki (Rozkosz, 2017a);

- analiza bibliografii autora lub grupy autorów - badania te są analizą dorobku publikacyjnego konkretnego autora, np. analiza prac Karola Głombiowskiego (Wańka, 2015; Nabiałczyk, 2015) lub dotyczą grupy badaczy wybranych według konkretnych kryteriów, np. analiza publikacji szczecińskich naukowców w bazie Web of Science (Klimko, 2016) i analiza cytowań publikacji członków komitetów naukowych Polskiej Akademii Nauk według Google Scholar (Siłka et al., 2016);

- analiza dziedziny lub dyscypliny naukowej - badania te obejmują analizy bibliometryczne dynamiki obiegu wiedzy w konkretnych naukach, analizy rozwoju konkretnej dyscypliny i jej piśmiennictwa, np. badań hydrogeologicznych (Kowalczyk, 2015), zarządzania zasobami ludzkimi (Durczak, 2017) lub polskich nauk medycznych (Olechnicka \& Płoszaj, 2015). W kategorii tej są także analizy relacji między dyscyplinami (np. Stachowiak \& Bajerski, 2016);

- analiza dorobku jednostki naukowej - badania te obejmują analizy działalności konkretnego uniwersytetu, np. Uniwersytet Mikołaja Kopernika w świetle danych incites (Czyżak, 2016). W grupie tej znajdują się także badania porównawcze placówek, np. geografia najlepiej ocenianych ośrodków akademickich (Bański, 2015) lub rankingi placówek (Barczyński, 2015);

- analiza publikacji - w bibliografii zarejestrowano pracę, która wykorzystuje metodę bibliometryczną do analizy zbiorowej publikacji wydanej na podstawie konferencji naukowej uznanej za reprezentatywną dla przeglądu bieżących kierunków w zakresie marketingu, handlu i konsumpcji (Wiktor, 2016).

Tab. 4. Rozkład chronologiczny publikacji według sposobu ujęcia tematu

\begin{tabular}{|c|c|c|c|c|c|}
\hline \multirow[b]{2}{*}{$\begin{array}{c}\text { Rok } \\
\text { publikacji }\end{array}$} & \multicolumn{4}{|c|}{ Liczba publikacji wg sposobu ujęcia tematu } & \multirow[b]{2}{*}{ Razem } \\
\hline & $\begin{array}{c}\text { Analiza } \\
\text { danych em- } \\
\text { pirycznych }\end{array}$ & $\begin{array}{l}\text { Prace o cha- } \\
\text { rakterze teo- } \\
\text { retycznym }\end{array}$ & $\begin{array}{c}\text { Komentarz } \\
\text { lub polemika }\end{array}$ & Inne & \\
\hline 2015 & 45 & 34 & 32 & 2 & 113 \\
\hline 2016 & 42 & 24 & 5 & 2 & 75 \\
\hline 2017 & 30 & 40 & 5 & 5 & 80 \\
\hline $\begin{array}{c}\text { Razem } \\
\text { w okresie } \\
2015-17\end{array}$ & 117 & 100 & 42 & 9 & 268 \\
\hline
\end{tabular}

Tabela 5 prezentuje rozkład ilościowy publikacji zakwalifikowanych do poszczególnych kategorii prac poświęconych badaniom empirycznym. 
Tab. 5. Tematy publikacji dotyczących badań empirycznych

\begin{tabular}{|l|c|}
\hline \multicolumn{1}{|c|}{ Kategoria tematyczna } & Liczba publikacji \\
\hline Analiza piśmiennictwa wybranego zagadnienia & 58 \\
\hline Analiza czasopisma & 22 \\
\hline Analiza bibliografii wybranego autora lub grupy autorów & 16 \\
\hline Analiza piśmiennictwa dziedziny lub dyscypliny naukowej & 13 \\
\hline Analiza dorobku jednostki naukowej & 7 \\
\hline Analiza publikacji & 1 \\
\hline Razem & 117 \\
\hline
\end{tabular}

Wśród 100 publikacji o charakterze teoretycznym można wyodrębnić 11 kategorii tematycznych:

- metodologia - badania te dotyczą metod wykorzystywanych w naukometrii i bibliometrii (m.in. Opaliński, 2017; Sitarz, 2015), nowych rozwiązań metodologicznych (Wais, 2016) oraz narzędzi wykorzystywanych w badaniach, np. Gephi (Osińska, 2017). W grupie tej znajdują się także prace omawiające wyzwania metodologiczne (Cena et al., 2015) oraz wskazówki dotyczące zbierania materiału badawczego w bibliometrii (Kamińska, 2017a);

- parametryzacja nauki - prace ujęte w tej grupie dotyczą problemów związanych z parametryzacją, np. jej wpływem na karierę naukową (Szczygłowska, 2015a), zjawiskiem tzw. punktozy (Kulczycki, 2017a), wyzwaniami instytucjonalnej ewaluacji nauki (Kulczycki, 2017b), ewaluacji osiągnięć naukowych w postępowaniu habilitacyjnym (Rozkosz, 2017b), a także kryteriami ocen i parametryzacji oraz oceny eksperckiej (Kulczyck et al., 2016);

- wskaźniki - badania te obejmują publikacje na temat poszczególnych indeksów wykorzystywanych w badaniach bibliometrycznych - ich opisy i krytykę, np. OpenCitations (Kamińska, 2017b) lub Journal Impact Factor (Towpik, 2015), wykorzystanie (Drabek, 2015), a także informacje o nowopowstałych indeksach (Theus, 2016);

- nauka w Polsce - prace w tej grupie dotyczą stanu naukometrii w Polsce oraz problemów polskiej nauki, m.in. systemu awansów naukowych (Brzeziński, 2017), sytuacji młodych naukowców (Zawadzki, 2017), zmian w szkolnictwie wyższym (Antonowicz, 2016), modeli szkolnictwa wyższego (Antonowicz, 2015) oraz opracowań na temat aktualnej debaty nad naukometrią i bibliometrią w Polsce (Kokowski, 2015b);

- wykorzystanie bibliometrii - badania te obejmują zagadnienia dotyczące wykorzystania parametrów i metod bibliometrycznych w poszczególnych dziedzinach wiedzy i dyscyplinach naukowych lub badaniach, np. w pracy bibliotekarza (Klimko, 2015), rejestracji działalności publikacyjnej (Garczyńska, 2017) lub działań menadżerskich na uniwersytecie (Szczygłowska, 2015b). Grupa ta obejmuje także zagadnienia rozwoju wykorzystania poszczególnych aspektów bibliometrii, np. jej diagnostycznej roli (Osiewalska, 2017) oraz wykorzystania bibliometrii do kształtowania polityki finansowania instytucji naukowych, opartej na ocenie jakości publikacji (Sivertsen, 2017); 
- bazy danych - w pracach tych analizowane są poszczególne bazy danych np. BazEkon (Narloch \& Nowosień, 2016) oraz ich wykorzystanie jako narzędzia bibliometrycznego (Hetman \& Pietrzyk-Leonowicz, 2015). W grupie tej znajdują się też badania porównawcze baz danych (Derfert-Wolf, 2016);

- czasopisma - prace zaliczone do tej grupy podejmują zagadnienia dotyczące roli czasopism w rozwoju nauki, problemów fałszywych edytorów (Sorokowski, 2017) i zjawiska tzw. drapieżnych czasopism (Kulczycki, 2017c), a także oceny czasopism i ich roli w transferze wiedzy (Alejziak, 2016);

- komunikacja naukowa - prace te podejmują zagadnienia komunikacji naukowej w badaniach bibliometrii (np. Skalska-Zlat, 2015);

- biblioteki - grupa ta obejmuje badania związane z udziałem bibliotek w procesie parametryzacji (Dziak et al., 2015), wpływem parametryzacji na potrzeby użytkowników biblioteki (Paruzel, 2015) oraz bibliometrycznej oceny bibliotek uniwersyteckich w Polsce (Ryś \& Chadaj, 2016);

- historia - badania te dotyczą historii oraz rozwoju bibliometrii i naukometrii (Godin, 2017; Kokowski, 2015a);

- inne - do tej grupy zakwalifikowano dwie prace, których tematyka nie pasuje do żadnej z wcześniej wymienionych kategorii. Pierwsza jest językoznawczą analizą słowa „punktoza” (Szczerbowski, 2017), a druga dotyczy zarządzania produktywnością naukową w kontekście budowania marki uczelni (Witczak \& Mitręga, 2015).

Tabela 6 prezentuje rozkład ilościowy publikacji o charakterze teoretycznym w wyodrębnionych kategoriach tematycznych.

Tab. 6. Tematy publikacji teoretycznych

\begin{tabular}{|l|c|}
\hline \multicolumn{1}{|c|}{ Kategoria tematyczna } & Liczba publikacji \\
\hline Metodologia & 27 \\
\hline Parametryzacja nauki & 22 \\
\hline Wskaźniki & 12 \\
\hline Nauka w Polsce & 9 \\
\hline Wykorzystanie bibliometrii & 8 \\
\hline Bazy danych & 7 \\
\hline Czasopisma & 5 \\
\hline Biblioteki & 3 \\
\hline Historia & 3 \\
\hline Komunikacja naukowa & 2 \\
\hline Inne & 2 \\
\hline Razem & 100 \\
\hline
\end{tabular}

Analiza tematyki publikacji o charakterze teoretycznym dowodzi, że metodologia stanowi główny przedmiot zainteresowań badaczy. Jest to niezwykle ważny temat ze względu na 
nowe rozwiązania metodologiczne, do których wykorzystywane są zmieniające się narzędzia oraz standardy prowadzenia badań. Nie zaskakuje także drugi z najbardziej popularnych tematów, tj. parametryzacja. Jej zastosowania są szeroko komentowanym problemem, związanym z oceną jakości nauki, jej rodzajami i zasadami, a także z wyznaczaniem jej prawnych regulacji.

Zaskakująca jest mała liczba publikacji związanych z historią naukometrii i bibliometrii. Oznaczać to może podejmowanie przez badaczy jedynie aktualnych problemów i nieprowadzenie badań mających na celu analizę standardów z przeszłości. Widoczny jest także brak zainteresowania tematami związanymi z sytuacją naukometrii i bibliometrii w innych krajach. Może to dziwić, bo przecież - badając i opisując obce wzorce - można wyciągnąć wiele użytecznych wniosków, które pozwalają wypracować standardy postępowania lepiej dostosowane do praktyki działalności naukowej we własnym kraju.

\section{Wnioski końcowe}

Podsumowując omówione wyżej wyniki analizy piśmiennictwa zarejestrowanego w bibliografii opracowanej przez Scholary Communication Research Group, warto wskazać kilka najważniejszych ustaleń. Według poddanego analizie źródła, w latach 2015-2017 w Polsce zagadnienia naukometrii i bibliometrii były podejmowane jako przedmiot lub metoda badań 268 razy. Ponieważ trudno jest ocenić kompletność analizowanej bibliografii, liczba ta może być traktowana jedynie jako wskaźnik istnienia wyraźnego zainteresowania tą problematyką wśród polskich badaczy. Ilościowy rozkład publikacji zarejestrowanych w tej bibliografii w poszczególnych latach, którego wykres znajduje się na stronie bibliografii (Rys. 1), wyraźnie dowodzi, że w ostatnich kilku latach to zainteresowanie rośnie.

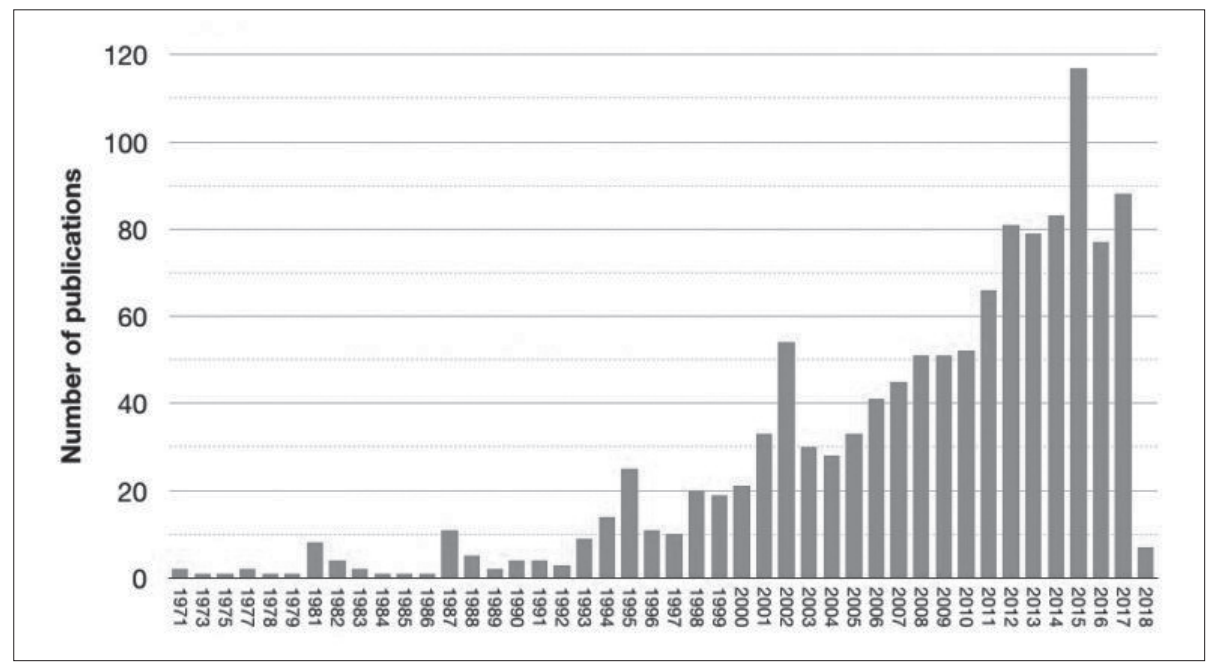

Rys. 1. Liczba publikacji zarejestrowanych w bibliografii SCRG (N=1199, aktualizacja 23 kwietnia 2018). Źródło: SCRG, 2018 
Analiza czasopism, w których opublikowane zostały prace na tematy z zakresu naukometrii i bibliometrii, wykazała, że można wyróżnić wśród nich dwie grupy periodyków: naukowe oraz informacyjno-publicystyczne. Wśród czasopism naukowych występują periodyki z dziedzin zarówno humanistycznych (np. historyczne, psychologiczne, socjologiczne i językoznawcze), jak i technicznych, medycznych i ekonomicznych. Oznacza to podejmowanie tematu naukometrii oraz wykorzystywanie metod bibliometrycznych przez badaczy reprezentujących różne dziedziny naukowe i równocześnie zainteresowanie tego typu problematyką czasopism z poszczególnych dziedzin, których dotyczą badania bibliolub naukometryczne. Sytuacja ta przyczynia się do znacznego rozproszenia piśmiennictwa biblio- i naukometrycznego. Analizowane artykuły zostały opublikowane na łamach 97 czasopism, średnio jedno czasopismo opublikowało dwa artykuły. Dane te oznaczają, że poszczególne czasopisma sporadycznie podejmują temat naukometrii i bibliometrii; trudno też dostrzec stabilność zainteresowania polskich czasopism w publikowaniu treści związanych z tymi zagadnieniami.

W analizowanym zbiorze literatury zarejestrowano 176 autorów, wśród których aż 74\% opublikowało tylko jedną pracę. Średnia liczba publikacji na jednego autora wynosi 1.5. Duża liczba autorów, którzy opublikowali w badanym okresie tylko jedną pracę dotyczącą naukometrii i bibliometrii oraz niski wskaźnik publikacji na jednego autora świadczą o sporadycznym podejmowaniu tego tematu przez polskich badaczy. Tylko czterech autorów opublikowało prace w każdym roku $\mathrm{z}$ analizowanego przedziału. A zatem można stwierdzić, że generalnie niewielu polskich naukowców długofalowo zajmuje się bibliometrią i naukometrią.

Wśród publikacji poddanych analizie wyodrębniono cztery ogólne typy: (1) publikacje poświęcone badaniom empirycznym, w których bibliometria i naukometria są metodą badawczą, (2) publikacje o charakterze teoretycznym (3) komentarze i polemiki, oraz (4) inne prace, obejmujące recenzje, bibliografie i listy.

Najliczniejszą grupę w badanym okresie stanowiły prace dotyczące badań empirycznych, w których bibliometria została wykorzystana jako metoda badań (44\%). Stosując kryterium przedmiotowe można wśród nich wyróżnić sześć typów analiz: analizy piśmiennictwa wybranego zagadnienia, analizy czasopism, analizy dorobku autora, analizy piśmiennictwa dziedziny lub dyscypliny naukowej, analizy dorobku jednostki naukowej oraz analizy publikacji lub innego konkretnego zjawiska niezwiązanego z wymienionymi kategoriami. W tej grupie najliczniej reprezentowane są analizy piśmiennictwa wybranego zagadnienia. Z kolei wśród publikacji o charakterze teoretycznym, które obejmują 37\% analizowanego zbioru, można wyróżnić 11 kategorii tematycznych: metodologia, parametryzacja nauki, wskaźniki, nauka w Polsce, wykorzystanie bibliometrii, bazy danych, czasopisma, biblioteki, historia, komunikacja naukowa, inne (jednostki naukowe i terminologia). Dość liczną grupą wśród zarejestrowanej literatury są także artykuły będące polemikami i komentarzami do badań, które stanowią 15.7\% wszystkich publikacji podejmujących tematykę biblio- i naukometrii. Najmniej liczną grupę stanowią publikacje takie jak: recenzję, bibliografie i listy (kategoria „Inne” w zaproponowanej kategoryzacji tematycznej), obejmuje ona 3.3\% analizowanego zbioru piśmiennictwa. 


\section{Bibliografia}

Alejziak, W. (2016). „Annals of Tourism Research” jako źródło wiedzy o osiągnięciach badawczych antropologii w dziedzinie turystyki. Folia Turistica, 39, 9-44.

Antonowicz, S., Brdulak, J., Hulicka, M., Jędrzejewski, T., Kowalski, R., Kulczycki, E., Szadkowski, K., Szot, A., Wolszczak-Derlacz, J., Kwiek, M. (2016). Reformować? Nie reformować? Szerszy kontekst zmian w szkolnictwie wyższym. Nauka, 4, 7-33.

Bański, J. (2017). Analiza dorobku publikacyjnego samodzielnych pracowników naukowych z polskich placówek geograficznych. Przeglad Geograficzny, 89 (4), 595-616.

Barczyński, B. J. (2015). Ranking of the Scientific Units of Polish Physical Education High Schools Based on Citations from Web of Science for the Period of 2009-2012 Indexed by the Polish Ministry of Science and Higher Education - Focus on Specialists in Science of Martial Arts. Archives of Judo, 11, 371-382.

Bartol, T., Mackiewicz-Talarczyk, M. (2015). Bibliometric Analysis of Publishing Trends in Fiber Crops in Google Scholar, Scopus, and Web of Science. Journal of Fibres Sciences, 12 (6), 531-54.

Broadus, R. N. (1987). Early Approaches to Bibliometrics. Journal of the American Society for Information Science, 38(2), 127-129.

Brzeziński, J. M. (2017). O poprawianiu (ale też i o psuciu) systemu przeprowadzania awansów naukowych w Polsce w latach 1990-2017. Nauka i Szkolnictwo Wyższe, 2, 147-172.

Czyżak, D. (2016). Uniwersytet Mikołaja Kopernika w świetle danych incites. W: E. Głowacka, M. Jarocki, N. Pamuła-Cieślak (red.) Wspótczesne oblicza komunikacji i informacji: przestrzeń informacyjna nauki (307-320). Toruń: Wydaw. Naukowe Uniwersytetu Mikołaja Kopernika.

Derfert-Wolf, L. (2016). Bazy bibliograficzne a POL-index - plusy, minusy, szanse, zagrożenia na podstawie doświadczeń BazTech [online]. Prezentacje z V WSB. V Wrocławskie Spotkania Bibliotekarzy, Wrocław, 15-16 września 2016 r. [22.06.2018], http://www.bibliotech.pwr.edu.pl/ wp-content/uploads/2016/09/01.-Lidia-Derfert-Wolf.pdf

Drabek, A. (2015). Gdzie szukać cytowań i jak je wykorzystywać? W: D. Bubel (red.) Zarzadzanie wiedza i informacja w aspekcie parametryzacji uczelni. Częstochowa: Wydaw. Wydziału Zarządzania Politechniki Częstochowskiej, 68-79.

Durczak, K., Koperska, A., Piasecki, P., Ławrynowicz, M. (2017). ZZL w ostrych barwach. Bibliometryczna analiza podejść i metod badawczych. Zarzadzanie Zasobami Ludzkimi, 115 (2), 31-50.

Dziak, J., Długaj, U., Skrzypiec, H. (2015). Udział biblioteki w procesie parametryzacji na przykładzie Biblioteki Głównej Politechniki Śląskiej., W: D. Bubel (red.) Zarzadzanie wiedza i informacja w aspekcie parametryzacji uczelni (80-88). Częstochowa: Wydaw. Wydziału Zarządzania Politechniki Częstochowskiej.

Garczyńska, M. (2017). Rejestracja działalności publikacyjnej w aspekcie wykorzystania danych bibliograficznych. W: A. Łuszpak, J. Leśniewski (red.) V Wrocławskie Spotkania Bibliotekarzy (85-94). Wrocław: Oficyna Wydawnicza Politechniki Wrocławskiej.

Godin, B. (2017). O początkach bibliometrii. Nauka i Szkolnictwo Wyższe, 1, 19-46.

Hetman, E., Pietrzyk-Leonowicz, S. (2015). Baza publikacji Politechniki Lubelskiej jako narzędzie bibliometryczne. W: D. Bubel (red.) Zarzadzanie wiedza i informacja w aspekcie parametryzacji uczelni (131-143). Częstochowa: Wydawnictwo Wydziału Zarządzania Politechniki Częstochowskiej.

Ivancheva, L. (2008). Scientometrics Today: A Methodological Overview. Collnet Journal of Scientometrics and Information Management, 2, 47-56.

Jaskulska, S. (2015). „Kultura - Społeczeństwo - Edukacja”. Dobre wzorce zakorzeniania się nowego czasopisma w rzeczywistości akademickiej. Rocznik Pedagogiczny, t. 38, 389-394.

Kamińska, A. M. (2017a). Tam, gdzie zaczyna się bibliometria, czyli jak pozyskać materiał analityczny z autopsji. Biuletyn EBIB [online], 173, 1-13, [22.06.2018], http://open.ebib.pl/ojs/index.php/ebib/ article/view/534/698 
Kamińska, A. M. (2017b). OpenCitations - otwarty indeks cytowań publikacji naukowych. Biuletyn EBIB [online], 176, 1-9., [22.06.2016], http://open.ebib.pl/ojs/index.php/ebib/article/view/551/746

Kamińska, J. (2015). Upowszechnianie czytelnictwa jako temat publikacji fachowych - próba bibliometrycznej analizy zagadnienia. W: M. Wojciechowska (red.) Czytelnictwo w dobie informacji cyfrowej. Rozwój, bariery, technologie (410-418). Gdańsk: Wydaw. Gdańskiego; Warszawa: Wydaw. SBP.

Klimko, R. (2015). Bibliometria w pracy bibliotekarza. Bibliotekarz Zachodniopomorski, (1), 15-20.

Klimko, R. (2016). O czym mówią cytowania. Publikacje szczecińskich naukowców w Web of Science. Przeglad Zachodniopomorski, (2), 161-173.

Kokowski M. (2015a). Science of Science (naukoznawstwo) in Poland. The Changing Theoretical Perspectives and Political Contexts - A Historical Sketch from the 1910s to 1993. Organon, (47), 147-237.

Kokowski, M. (2015b). Szkic aktualnej debaty nad naukometrią i bibliometrią w Polsce i zapomniane naukoznawstwo. Prace Komisji Historii Nauki PAU, (14), 117-134.

Kulczycki, E. (2017a). Punktoza jako strategia w grze parametrycznej w Polsce. Nauka i Szkolnictwo Wyższe, (1), 63-78.

Kulczycki, E. (2017b). Wprowadzenie. Wyzwania instytucjonalnej ewaluacji nauki. Nauka i Szkolnictwo Wyższe, (1), 7-15.

Kulczycki E. (2017c). Kariera drapieżnych czasopism - przypadek Anny O. Szust. Nauka (nr 3), 71-83.

Kulczycki, E., red. (2017). Komunikacja naukowa w humanistyce. Poznań: Wydaw. Naukowe IF UAM.

Kulczycki, E., Rozkosz, E.A., Drabek, A. (2016). Ocena ekspercka jako trzeci wymiar ewaluacji krajowych czasopism naukowych. Nauka, (1), 107-142.

Nabiałczyk, K. (2015). Stań na ramionach olbrzymów: bibliometryczne studium przypadku wybranych prac Karola Głombiowskiego. W: R. Aleksandrowicz, H. Rusińska-Giertych (red.) Książka i biblioteka w procesie komunikacji społecznej (39-74). Wrocław: Oficyna Wydawnicza Atut-Wrocławskie Wydaw. Oświatowe.

Narloch, A., Nowocień, T. (2016). BazEkon - wiodąca baza ekonomiczna z pierwszym w Polsce indeksem cytowań. Bibliotekarz Zachodniopomorski, (2), 10-14.

Niklewicz-Pijaczyńska, M. (2015). Rola systemu patentowego w dyfuzji wiedzy. Studia Ekonomiczne (Katowice), (214), 242-252.

Olczyk, M. (2015). Konkurencyjność w literaturze ekonomicznej - analiza bibliometryczna. Prace Naukowe Uniwersytetu Ekonomicznego we Wroctawiu, (401), 338-348.

Olechnicka, A., Płoszaj, A. (2015). Pozycja polskich nauk medycznych na arenie międzynarodowej. Warszawa: Biuro Promocji Nauki PAN.

Opaliński, Ł. (2017). Bibliometryczna metodologia prognozowania i oceny rozwoju dyscyplin naukowych. Analiza piśmiennictwa. Część I: Publikacje pionierskie, metoda powiązań bibliograficznych, metoda współcytowań i metoda współwystępowania specjalistycznej. Zagadnienia Informacji Naukowej - Studia Informacyjne, 55(1), 34-65.

Osiewalska, A. (2017). Rozwój diagnostycznej roli bibliometrii - wybrane aspekty. W: R. Sapa (red.) Diagnostyka w zarzadzaniu informacją: perspektywa informatologiczna (245-262). Kraków: Biblioteka Jagiellońska.

Osińska, V. (2017). Gephi - nowoczesne narzędzie do wizualizacji danych bibliometrycznych. Biuletyn $E B I B$ [online], 173, 1-8, [22.06.2018], http://open.ebib.pl/ojs/index.php/ebib/article/view/537/692

Paruzel, A. (2015). Wpływ parametryzacji na potrzeby użytkowników biblioteki uczelnianej na przykladzie Oddziału Informacji Naukowej Biblioteki Głównej Politechniki Częstochowskiej. W: D. Bubel (red.) Zarzadzanie wiedza $i$ informacja w aspekcie paremetryzacji uczelni (115-130). Częstochowa: Wydaw. Wydziału Zarządzania Politechniki Częstochowskiej.

Pindlowa W. (1988). Bibliometria i jej znaczenia dla badań nad książką. Studia o Książce, (17), 301-327.

Pritchard A. (1969). Statistical Bibliography or Bibliometrics? Journal of Documentation, 25(4), 348-349. 
Roszkowski, M., Włodarczyk, B. (2016). Cytowania zasobów sieciowych w polskich czasopismach z zakresu bibliotekoznawstwa i informatologii: analiza aktualności adresów URL. Zagadnienia Informacji Naukowej - Studia Informacyjne, 54(1), 21-43.

Rozkosz, E. A. (2017a). Czasopisma pedagogiczne w „Wykazach czasopism punktowanych” w latach 2012, 2013 i 2015. W: E. Kulczycki (red.) Komunikacja naukowa w humanistyce (153-173). Poznań: Wydaw. Naukowe IF UAM.

Rozkosz, E. A. (2017b). Ewaluacja osiagnięć naukowych w postępowaniach habilitacyjnych. Kryteria oceny a praktyki ewaluacyjne w naukach humanistycznych $i$ spotecznych. Praca doktorska. Promotorzy: E. Kulczycki, N. Pamuła-Cieślak. Toruń: Uniwersytet Mikołaja Kopernika.

Ryś D., Chadaj, A. (2016). Bibliometrics and Academic Staff Assessment in Polish University Libraries - Current Trends. LIBER Quarterly, 26 (3), 181-199.

SCRG (2018). Bibliography | Scholarly Communication Research Group [online]. Adam Mickiewicz University in Poznań [18.04.2018], http://sc.amu.edu.pl/bibliography/

Seweryn, A. (2016). International Flows of Book Translations (1981 - 2000). Findings and Conclusions from the Quantitative Study. Katowice 2016.

Siłka, P., Śleszyński, P., Jaworska, B. (2016). Cytowania członków komitetów naukowych Polskiej Akademii Nauk według Google Scholar. Zagadnienia Naukoznawstwa, 52(4), 529-560.

Sitarz, R., Heneczkowski, M., Jabłońska-Sabuka, M., Krasławski, A. (2015). Clustering Method for Analysis of Research Fields: Examples of Composites, Nanocomposites and Blends. W: D. Filev, J. Jablkowski, J. Kacprzyk, M. Krawczak, I. Popchev, L. Rutkowski, V. Sgurev, E. Sotirova, P. Szynkarczyk, S. Zadrozny (eds.) Intelligent Systems'2014, Vol 2: Tools, Architectures, Systems, Applications (431-442). Berlin: Springer Verlag.

Sivertsen, G. (2017). Finansowanie oparte na publikacjach - Model norweski. Nauka i Szkolnictwo Wyższe, (1), 47-60.

Skalska-Zlat, M. (1996). Bibliografia jako przedmiot i narzędzie badań. W: A. Karłowicz, D. Bilikiewicz-Blanc (red.), Czwarta Ogólnokrajowa Narada Bibliografów, Warszawa 7-9 czerwca 1995 (50-62). Warszawa: Biblioteka Narodowa.

Skalska-Zlat, M. (2015). Komunikacja piśmiennicza w badaniach bibliometrii. W: E. Gondek (red.) Teoretyczne zagadnienia bibliologii i informatologii (159-172). Katowice: Wydaw. Uniwersytetu Śląskiego.

Sorokowski, P., Kulczycki, E., Sorokowska, A., Pisanski, K. (2017). Predatory Journals Recruit Fake Editor. Nature [online], 543(7646), 481-483, DOI: 10.1038/543481a

Stachowiak, K., Bajerski, A. (2016). Relations of Geography with Other Disciplines. A Bibliometric Analysis. Geographia Polonica, 89 (2), 203-219.

Szczerbowski, T. (2017). „Punktoza” jako słowo ostatnich lat. Poradnik Językowy, (7), 80-87.

Szczygłowska, L. (2015). May a Scientists' Career Be Reduced to a One-Dimensional Measurement. W: D. Bubel (red.) Zarzadzanie wiedza i informacja w aspekcie parametryzacji uczelni (211-225). Częstochowa: Wydaw. Wydziału Zarządzania Politechniki Częstochowskiej, 211-225.

Szczygłowska, L. (2015). Characterictics of Bibliometric Measures Used in the Management of the University. W: D. Bubel (red.) Zarzadzanie wiedza i informacja w aspekcie parametryzacji uczelni (193-210). Częstochowa: Wydaw. Wydziału Zarządzania Politechniki Częstochowskiej.

Theus, M. (2016). Emerging Sources Citation Index (ESCI) : nowy indeks w bazie Web of Science szansą dla czasopism. Poradnik Bibliotekarza, (11), 11-13.

Towpik, E. (2015). IF-mania: Journal Impact Factor nie jest właściwym wskaźnikiem oceniania wyników badań naukowych, indywidualnych uczonych ani ośrodków badawczych. Nowotwory. Journal of Oncology, 65 (6), 465-475.

Wach, K. (2016). Edukacja przedsiębiorcza: analiza bibliometryczna polskiego piśmiennictwa. Horyzonty Wychowania, 15 (34), 11-26.

Wais, K. (2016). Gender Prediction Methods Based on First Names with genderizeR. R Journal, 8 (1), 17-37. 
Wańka, D. (2015). Prace Karola Głombiowskiego w artykułach opublikowanych w latach 1987-2012 na łamach wybranych polskich czasopism naukowych: analiza cytowań. W: R. Aleksandrowicz, H. Rusińska-Giertych (red.) Ksiażka i biblioteka w procesie komunikacji społecznej (75-91). Wrocław: Oficyna Wydawnicza Atut-Wrocławskie Wydaw. Oświatowe.

Witczak, O., Mitręga, M. (2015). Zarządzanie produktywnością naukową w kontekście budowania marki uczelni wyższej. Zeszyty Naukowe Uniwersytetu Szczecińskiego. Problemy Zarzadzania, Finansów i Marketingu, 41 (1,) 415-424.

Zawadzki, M. (2017). Między neoliberalizmem a feudalizmem. Godność młodych naukowców w kontekście transformacji polskiego uniwersytetu. Nauka i Szkolnictwo Wyższe, 1, 133-154.

\title{
Scientometrics and Bibliometrics Researches in Poland in 2015-2017
}

\begin{abstract}
Purpose/Thesis: The purpose is to examine the way bibliometrics and scientometrics were used - as a research problem and a scientific method, in Poland in the years 2015 to 2017.

Approach/Methods: The research was based on the contents of the bibliography of Polish scientometrics created by the Scholarly Communication Research Group; available at http://sc.amu.edu.pl/ bibliography/. The statistical method was used to assess the quantitative changes in the literature in the examined period, determine the thematic structure and indicate the most active authors and journals. Results and conclusions: In the years 2015 to 2017 there were 268 documents related to scientometrics and bibliometrics registered in Poland. Four categories of documents were distinguished: documents in which bibliometrics is used as a research method (44\%), theoretical works (37\%), comments and polemics (15.7\%) and others (3.3\%). The analysis of journals shows that Polish journals sporadically address the subject of scientometrics and bibliometrics. The journals researched included periodicals in the field of humanities, technology, medicine and economics. The analysis of authors shows that researchers rarely pursue this subject as well and only a few Polish scientists are researching this issue in the long term.

Originality/Cognitive value: The article organizes knowledge about the current context of scientometric and bibliometric research in Poland.
\end{abstract}

Keywords

Bibliometrics. Information science. Research in Poland. Scientometrics.

Mgr MAGDALENA SZNIGIR jest absolwentka kierunku Informacja naukowa i bibliotekoznawstwo na Uniwersytecie Wrocławskim. Obecnie pracuje w pozarzadowej organizacji KASA Fondation Humanitaire Suisse w Erywaniu (Armenia). Do jej gtównych zainteresowań badawczych należa kierunki rozwoju informacji naukowej oraz dydaktyka w zakresie informacji naukowej i bibliotekoznawstwa w Europie Wschodniej.

Kontakt $z$ autorka:

sznigir.magdalena@gmail.com

Adres korespondencyjny:

Bryusov 2 ap. 6,

Yerevan 0023, Armenia 